\title{
СТАНОВЛЕНИЕ И ОСОБЕННОСТИ ПРАВОВОЙ СИСТЕМЫ ИЗРАИЛЯ КАК СМЕШАННОЙ ЮРИСДИКЦИИ
}

\begin{abstract}
Аннотация: В статье рассматривается генезис развития правовой системы Израиля. Дается характеристика основных элементов, повлиявших на формирования современного израильского права, а также выделяется ряд особенности правовой системы Государства Израиль как составной части смешанной правовой семьи.Современный Израиль, сформировавшийся на стыке западных и восточных традиций представляет собой уникальное культурное и правовое образование. Исходя из этого, исследование правовой действительности Государства Израиль, как до его создания в 1948 году, так и в ходе дальнейшего государственно-правового становления, имеет не только важное научное значение, но и представляет значительный практический интерес. На основе приемов и способов системного анализа проводится исследование исторических нормативно-правовых документов, действующего израильского законодательства, а также трудов зарубежных и отечественных ученых по исследованию израильской правовой действительности. По результатам исследования автором делается вывод, что изучения опыта «смешанной» правовой организации и функиионирования Израиля может быть полезным для развития и совершенствования правовых систем во всем мире, так как именно данные системы являют собой пример инновации и модернизации в праве.
\end{abstract} Ключевые слова: Правовая система Израиля, правовая конвергенция, смешанная юрисдикция, общее право, прецедентное право, континентальное право, глобализация, аккультурация, мультикультурализм, правовая среда.

Abstract: This article examines the genesis of development of the legal system of Israel. The author gives characteristics to the main elements, which affected the formation of the current Israeli law, as well as determines certain peculiarities of the legal system of the State of Israel as an integral component of the mixed legal family. The modern Israel, formed across the Western and Eastern traditions, represents a unique cultural and legal institution. Based on this fact, the study of legal reality of the State of Israel before its establishment in 1948, as well as during its further state and legal development, presents a significant practical interest. The author analyzes the historical normative legal documents of the current Israeli legislation along with the works of foreign and Russian scholars regarding the examination of legal reality of Israel. Based on the results of this research, the conclusion is made that the study of experience of the "mixed" legal organization and functionality of Israel can be useful for development and improvement of legal system throughout the world, because namely such systems demonstrate an example of innovation and modernization in law.

Keywords: Multiculturalism, acculturation, globalization, civil law, case law, common law, mixed jurisdiction, legal convergence, Israeli law, legal environment.

ктуальность исследования феномена смешанных правовых систем объясняется всё более наметившимися тенденциями к интеграции и гармонизации в рамках правовой действительности Особое место Государства Израиль в ряду смешанных юрисдикций обусловлено тем, что оно, наряду с Шотландией, является единственным государством, которое свободно избрало смешанную систему. В этой связи рассмотрение правовой системы Государства Израиль представляет собой повышенный интерес и практическую важность.

Специфика генезиса правовой системы «еврейского и демократического» государства, породила ряд условий, позволяющих её охарактеризовать как «смешанную юрисдикцию».
Во-первых, судейское право по-прежнему является важной составной частью правовой системы Израиля [12, p.979]. По существу, за много лет был развит богатый массив израильского общего права, как в области публичного права, так и в области частного права. Кроме того, прецедент является одним из источников права, что закреплено в Основном законе о судебной власти (1984). В ст. 20 Закона указывается, что суд руководствуется судебным прецедентом, установленным вышестоящим судом. Далее отмечается, что прецедент, установленный Верховным судом, обязателен для всех судов, кроме него самого[1]. Более того, судебные решения сформулированы в духе традиции общего права, и отличаются от идей и принципов, принятых за основу по 


\section{Право и политика $12(204) \cdot 2016$}

аналогичному вопросу в континентальных правовых системах. Скорее всего, это сочетание «цепного романа» (используя выражение Р. Дворкина) [5, р.165168], в котором судья связан с правовой историей и творческими судебными начинаниями. Суть в том, что судья, подобно автору цепного романа, должен быть связан предыдущим решением. Он должен рассмотреть прошлые решения в рамках продолжающейся истории. Каждое решения судья пишет, придерживаясь ранее принятого [11,p. 1-14].

Следует отметить, что израильское прецедентное право являет собой типичный пример права стран, придерживающихся традиций английского общего права. Судьи прибегают к такой деятельности часто под видом толкования в формулировках, относящихся к основополагающим конституционным принципам (особенно касающимся свободы личности). С годами в Израиле сложился особый свод прецедентного права на базе решений Верховного суда, утверждающий фундаментальные гражданские права, такие как свобода слова, собраний, вероисповедания и равенство всех перед законом, - в качестве основных ценностей израильской правовой системы.

Во-вторых, примером смешанности является конституционный режим, вобравший в себя правовые концепции, как от континентального права, так и от общего права. В то время как в Государстве Израиль отсутствует писаная конституция, в стране действует Билль о правах (основные законы), принятый парламентом ${ }^{1}$. Однако, как считают израильские правоведы, Билль носит «неполный» характер, т.к. не закрепляет ряд фундаментальных гражданских прав, таких как свобода слова, свобода вероисповедания и право на равенство [10, р.786-787].

В 1995 г. Верховный суд Израиля принял решение, ссылаясь на знаменитое решение по делу Марбери против Мэдисона (1803 г.), что он обладает полномочиями по отмене законов и объявлению их недействительными [2]. В своем решении Верховный суд опирался на ограничительную оговорку, включенную в новые Основные законы и вдохновленную Канадской хартией прав и свобод 1982 г. [14, с. 57-63] С тех пор под влиянием американской концепции прав и свобод граждан, а также европейской концепции достоинства человека и его прав (например, ст.1 Основного закона ФРГ 1949 г.) Верховным судом разработан целый ряд конституционных норм, вытекающих из Основных законов.

\footnotetext{
${ }^{1}$ В 1992 году Кнессет принял два Основных закона, которые закрепили конституционный статус ряда основных прав и свобод, впоследствии став ядром Билля: Основной закон о свободе занятий и Основной закон о достоинстве и свободе человека.
}

В-третьих, пример сочетания различных правовых культур может быть найден в сфере регулирования частного права. В частности, израильский Ордонанс о деликтах, принятый во время британского мандата, отражает дух общего права при помощи кодификации действующего деликтного права в один связанный, юридически обязательный правовой документ. На протяжении многих лет израильские суды разработали, шаг за шагом, собственную доктрину общего права, интерпретируя язык Ордонанса в соответствии с требованиями времени. Например, понимание судами установленной дефиниции небрежности развивалось на протяжении многих лет и включает, в частности, знаменитую «формулу Хэнда»[3], и это несмотря на то, что Ордонанс по-прежнему отражает правило, указанное в решении по делу Донохью против Стивенсона [4]. В дальнейшем, обновленное определение небрежности получило свое закрепление в проекте Гражданского кодекса Израиля ${ }^{2}$.

И наконец, еще одним примером смешения различных правовых культур в правовой системе Государства Израиль является использование сравнительно - правовых исследований в израильской судебной практике. Как отмечалось ранее, иностранное право исторически являлось составной частью правовой системы страны. После 1980 г. английское общее право окончательно перестало «связывать» израильскую правовую систему, что, однако, не ограничило право судей использовать широкую палитру юридических инструментариев в виде использования правовой компаративистики при решении дел. Вместе с тем уместным является замечание ученых, что ссылка на иностранное право является полезной лишь в случаях, когда упомянутое законодательство является актуальным и направлено на улучшение деятельности судьи [10, р.781]. При этом считаем, что использования множества различных источников права способствует гармонизации между различными юрисдикциями, особенно во времена усиливающейся глобализации. Однако не стоит забывать, что для должного использования заимствований из иностранного права, необходимо обладать значительными знаниями и опытом, как иностранного права, так и национального права. В этой связи, целесообразнее и полезнее обращаться в целом к духу иностранного права, анализу мыш-

\footnotetext{
${ }^{2}$ Американским судьей Лернедом Хэндом в 1947 г. было предложено правило по которому поведение индивида признается небрежным, если издержки адекватных мер предосторожности, необходимых для предотвращения несчастного случая, для данного индивида меньше, чем потери в результате несчастного случая, умноженные на увеличение (в результате его действий) вероятности возникновения несчастного случая.
} 
ления иностранного законодателя, а не к решению частных вопросов, связанных с получением сиюминутного результата по конкретному делу, сродни «калифу на час».

В целом, широкое применение иностранного права сформировала как сферу публичного права, так и рамки частного права. Вероятнее всего, что готовность израильских судей на протяжении многих десятилетий перенимать опыт у своих иностранных коллег является результатом «смешанной» правовой истории Государства Израиль, а также является «смешанных» личных историй судей. В этой связи, израильские исследователи Т. Гидрон и С. Гольдштейн отмечают, человеческий фактор явился в качестве одного из лейтмотивов уникальности права Государства Израиль. Отцы-основатели независимой израильской правовой системы были преимущественно еврейскими юристами, которые прошли подготовку в континентальной Европе (особенно в Германии, Австрии и Италии) и бежавшими от нацистской тирании в подмандатную Палестину в 1930-х гг. ${ }^{3}$ Несмотря на опыт в охваченной фашистами Европе, эти правоведы сохранили сильную близость к континентальному частному праву. Они и их ученики, явились «моментом силы», запустившим процесс проникновения и принятия доктрины континентального права в израильское частное право [6, p.147].

Иную точку зрения на причины, послужившие основанием для смешения правовой системы общества еврейского государства, предлагает А. Лиховски, выдвигающий тезис о том, что израильское общество на начальных этапах своего становления, после завершения периода Мандата, не чувствовало себя созревшим для установления новой израильской идентичности. По мнению автора, ранние годы израильской государственности отражают общество, которое являлось «поколением пустыни с гибридной культурой» и, исходя из этого, было необходимым дождаться сформирования «нового израильского общества» перед проведением значительных изменений и принятия революционных решений касаемо путей формирования характера права в Государстве Израиль [9, p.287]. При этом отмечается, что, если бы «правовая революция» всё же состоялась, то правовая система Израиля пошла по одному из двух путей - континентальному [праву] или иудейскому [праву] [9, р.253].

\footnotetext{
${ }^{3}$ Двое первых судей Верховного суда были приверженцами романо-германской правовой культуры, третий учился в НьюЙорке, а четвертый получил образование в Англии. Пятый судья Верховного суда (раввин Симха Ассаф) не имел формального юридического образования.
}

Проанализировав элементы, исторически повлиявшие на формирование правовой системы Государства Израиль, можно привести ряд особенностей, характеризующих израильское право на современном этапе развития. Так, Д.Я. Примаков отмечает, что первая особенность израильского права состоит в том, что весь корпус законодательно-правовых актов, оставшийся в наследие от Османской и Британской империй в Палестине, был воспринят в первые десятилетия существования Израиля как основание для правоприменительной и законодательной деятельности. Так, система религиозных систем в Израиле - это наследие британского мандата, переданного Лигой Наций, от 24 февраля 1922г. [15, с.144-156].

Вторая особенность израильской правовой системы - это наследие законодательства османского периода, главным образом в области гражданского законодательства (Маджалла) и земельных отношений.

Третья особенность состоит в том, что юридическая доктрина с момента Мандата находится под сильным влиянием англо-американской правовой мысли. В течение этого периода удалось создать впечатляющее сбалансированное законодательство. После того как Израиль обрел независимость, израильские судьи и участники уголовного процесса охотно ссылались на уголовные дела США и Англии при выстраивании своей позиции и постановления приговора.

Четвертая особенность заключается в том, что в Израиле, отсутствует писаная конституция. Здесь можно выделить две основные причины: во-первых, влияние английской правовой традиции, и, во-вторых, противодействия со стороны религиозных (ортодоксальных) организаций, считающих, что Закон Божий, выраженный в Торе и ТаНаХе, является единственно возможной конституцией [13, с.40].

Пятая особенность, и возможно, ключевая: израильское законодательство вобрало в себя огромный корпус, который можно отнести к области иудейского права.

В дополнение, принципиальное различие между израильским подходом и сущностью других гибридных правовых систем заключается в том, что выбор определенного правового вектора развития, в Израиле, был предметом исключительно решения законодателя. Кроме того, необходимо подчеркнуть, что израильское государство зародилось как система общего права, но в дальнейшем сделала шаги в сторону континентального права, «так что теперь это двойное смешение» [7, p.449].

В заключении можно сделать ряд выводов, касающихся осмысления становления и развития израильского права. 


\section{Право и политика $12(204) \cdot 2016$}

Во-первых, правовую систему Израиля можно в полной мере охарактеризовать в качестве примера «смешанной юрисдикции». Доказательством этому служит одновременное функционирование в рамках одной страны как элементов светского права, выраженного в наличии черт континентальной и англо-саксонской правовой традиции, так и правовых систем религиозной направленности, в первую очередь иудейского права.

Во-вторых, значительное влияние религии на формирование социального и правового сознания, характеризующиеся наличием системы религиозных судов, а также правовой монополией в области регулирования личного статуса. В свою очередь, антагонизм между светскими и религиозными властями усиливается нарастающим вмешательством религиозных деятелей в политическую жизнь страны.

В-третьих, важной составляющей формирования правовой системы Израиля явилось наличие уникального «человеческого симбиоза». Именно разноплановость правового воспитания «отцовоснователей» сыграла, по нашему мнению, решающую роль в построении мультикультурализма современной израильской правовой системы.

В-четвертых, в дальнейшем развитии правовой системы Израиля прослеживаются следующие тенденции: 1) усиления континентальной правовой традиции в области частного права, что связано с работой над проектом Гражданского кодекса Израиля; 2) в области публичного права, дальнейшее усиление позиций израильского прецедентного права. Данное положение дел обусловлено, в первую очередь, той ролью, которую в правовом развитии играет Верховный Суд Израиля, в частности, по сохранению баланса между «еврейским и демократическим»в государстве; 3) усиление законодательной роли религиозных партий.

\section{Библиография:}

1. Basic Law: The Judiciary, 1984, SH 78, s 20, URL: http://knesset.gov.il/laws/special/eng/BasicLawTheJudiciary.pdf (дата обращения: 22.11.2016)

2. CA 6821/93 Bank Mizrahi v Migdal Cooperative Village. // Israel Law Reports. 1995. 2. 1. P. 220-223.

3. CA 5604/94 Hemed v State of Israel. 2004. IsrSC 58(2) 498, URL: http://www.court.gov.il/heb/home.htm.

4. Donoghue v Stevenson, [1932] AC 562 at 580, [1932] All ER Rep 1 HL (Eng).

5. Dworkin Ronald A. 'Natural' Law Revisited // University of Florida Law Review.1982. 34:2. p.165-188.

6. Goldstein S. Israel: Creating a New Legal System from Different Sources by Jurists of Different Backgrounds. Studies in Legal Systems: Mixed and Mixing in Esin Orucu, Elspeth Attwooll and Sean Coyle (eds),. Kluwer, 1996. 384 p.

7. Goldstein S. Israel Reports. Mixed Jurisdictions Worldwide: The Third Legal Family (Ed. by Palmer Vernon V.). N.Y.: Cambridge University Press, 2003. 577-610 pp.

8. Harris R. The Preservation of legal Traditions in Post-colonial Societies: A Comment.Jerusalem and the British Mandate: Interaction and Legacy (ed. by Y. Ben-Arieh). Jerusalem, 2003. 522 p.

9. Likhovski A. Between Two Worlds: The Legacy of the Law of Mandatory Palestine. Jerusalem and the British Mandate: Interaction and Legacy (ed. by Y. Ben-Arieh). Jerusalem, 2003. 522 p.

10. Rivlin E. Israel as a mixed jurisdiction // McGill Law Journal. 2012.57 (4). p.781-790.

11. Rivlin E. Thoughts on Referral to Foreign Law, Global Chain-Novel, and Novelty // Florida Journal of International Law. 2009. 21:1. p.1-27.

12. Shetreet S. Judicial Independence and Accountability in Israel // International and Comparative Law Quarterly. 1984.33. p. 979-1012.

13. Воробьев В.П. Государство Израиль: правовые основы возникновения и статус личности. М., 2001. 167 с.

14. Примаков Д.Я. Израильская модель судейского активизма // Право и политика. 2014. № 1. С. 57-63.

15. Примаков Д.Я. Становление израильского права глазами израильских правоведов // Правоведение. 2010. № 6. С. 144-156.

\section{References (transliterated):}

1. Dworkin Ronald A. 'Natural' Law Revisited // University of Florida Law Review.1982. 34:2. p.165-188.

2. Goldstein S. Israel: Creating a New Legal System from Different Sources by Jurists of Different Backgrounds. Studies in Legal Systems: Mixed and Mixing in Esin Orucu, Elspeth Attwooll and Sean Coyle (eds),. Kluwer, 1996. 384 p.

3. Goldstein S. Israel Reports. Mixed Jurisdictions Worldwide: The Third Legal Family (Ed. by Palmer Vernon V.). N.Y.: Cambridge University Press, 2003. 577-610 pp.

4. Harris R. The Preservation of legal Traditions in Post-colonial Societies: A Comment.Jerusalem and the British Mandate: Interaction and Legacy (ed. by Y. Ben-Arieh). Jerusalem, 2003. 522 p.

5. Likhovski A. Between Two Worlds: The Legacy of the Law of Mandatory Palestine. Jerusalem and the British Mandate: Interaction and Legacy (ed. by Y. Ben-Arieh). Jerusalem, 2003. 522 p.

6. Rivlin E. Israel as a mixed jurisdiction // McGill Law Journal. 2012. 57 (4). p.781-790. 
DOI: $10.7256 / 1811-9018.2016 .12 .21206$

При цитировании этой статьи сноска на doi обязательна

Государственные институты и правовые системы

7. Rivlin E. Thoughts on Referral to Foreign Law, Global Chain-Novel, and Novelty // Florida Journal of International Law. 2009. 21:1. p.1-27.

8. Shetreet S. Judicial Independence and Accountability in Israel // International and Comparative Law Quarterly. 1984. 33. p. 979-1012.

9. Vorob'ev V.P. Gosudarstvo Izrail': pravovye osnovy vozniknoveniya i status lichnosti. M., 2001. 167 s.

10. Primakov D.Ya. Izrail'skaya model' sudeiskogo aktivizma // Pravo i politika. 2014. № 1. S. 57-63.

11. Primakov D.Ya. Stanovlenie izrail'skogo prava glazami izrail'skikh pravovedov // Pravovedenie. 2010. № 6. S. 144-156. 